\title{
Distribution, diversity and ecology of modern freshwater ostracodes (Crustacea), and hydrochemical characteristics of Lago Petén Itzá, Guatemala
}

\author{
Liseth PÉREZ*, Julia LORENSCHAT, Rita BUGJA, Mark BRENNER ${ }^{1)}$, Burkhard SCHARF and Antje SCHWALB \\ Institute of Environmental Geology, University of Braunschweig, Langer Kamp 19c, 38106, Braunschweig, Germany \\ ${ }^{1)}$ Department of Geological Sciences \& Land Use and Environmental Change Institute, University of Florida, Gainesville, Florida, \\ FL 32611, USA \\ *e-mail corresponding author:1.perez@tu-bs.de
}

\begin{abstract}
We analyzed modern ostracode species assemblages and water column physico-chemical characteristics in Lago Péten Itzá, Guatemala. Lake waters are dominated by sulfate, bicarbonate, calcium and magnesium and display a total ion concentration of $\sim 11$ meq $L^{-1}$. Eleven extant ostracode species were identified. We found higher abundances of living ostracodes, as well as relatively higher species richness (eight species) and biodiversity ( $H$ of 1.6) between the littoral zone and a water depth of $20 \mathrm{~m}$. At water depths $>40 \mathrm{~m}$, these variables all decreased. The thermocline is located at a water depth of $\sim 20-40 \mathrm{~m}$. Cluster analysis revealed three water depth ranges in the lake of importance to ostracode distribution: 1) littoral zone (0.1-3 m), 2) water depths from the base of the littoral zone to the base of the thermocline $(3-40 \mathrm{~m})$, and 3) water depths below the thermocline $(40-160 \mathrm{~m})$. The assemblage "Darwinula-Heterocypris-Pseudocandona-Strandesia" is characteristic of waters $<15 \mathrm{~m}$. The "Cypridopsis-Cytheridella-Limnocythere" assemblage characterizes waters $<40 \mathrm{~m}$ and "Physocypria" indicates waters $>40 \mathrm{~m}$. Ostracode taxa from Lago Petén Itzá show specific ecological preferences related to water depth and associated physico-chemical characteristics, thus illustrating the potential of ostracodes as indicators of lake level changes and hydrodynamics.
\end{abstract}

Key words: freshwater ostracodes, ecology, Lago Petén Itzá, Guatemala, hydrochemistry, water depth

\section{INTRODUCTION}

Ostracodes are microscopic bivalved crustaceans that are often used for paleolimnological and paleoclimate reconstruction owing to their high abundance, wide distribution, good preservation in lake sediments, and their sensitivity to many environmental factors. Their utility in some regions is limited, especially where little is known about their modern ecological preferences. Investigation of the modern ostracode fauna and species ecologies in Lago Petén Itzá, Guatemala, became a priority when the lake was selected for paleolimnological study by the International Continental Scientific Drilling Program (ICDP). One objective was to use microfossils in sediment cores as proxies for past climatic and environmental changes in the lowland Neotropics.

Ostracodes, also called "mussel shrimps," are generally $0.7-1.0 \mathrm{~mm}$ long, but their size ranges between 0.3 and $5.0 \mathrm{~mm}$ in freshwater systems. Their valves are composed of low-Mg calcite (Bridgwater et al. 1999; Dole-Olivier et al. 2000; Griffiths \& Holmes 2000; Brenner et al. 2002; Horne et al. 2002; Schwalb 2003; Scharf 2005). They are distributed worldwide and live in almost all aquatic environments, including lakes, rivers, groundwaters, estuaries, and oceans. Previous research has shown that ostracodes are sensitive to changes in water variables such as temperature, conductivity, $\mathrm{pH}$, and depth, as well as substrate type, aquatic macrophyte cover and energy level of the environment (Smith 1993; Mourguiart \& Carbonel 1994; Holmes 1996; Horne et al. 2002; Smith \& Horne 2002; Viehberg 2005; Frenzel et al. 2006; Mischke et al. 2007). Ostracodes from water bodies in the Petén Lake District, Guatemala, were shown to be useful for paleoclimate reconstructions in the region (Goulden 1966; Curtis et al. 1996; Leyden et al. 1996; Whitmore et al. 1996; Curtis et al. 1998; Brenner et al. 2002; Rosenmeier et al. 2002a, b; Hillesheim et al. 2005; Hodell et al. 2005; Escobar et al. 2009). For instance, Holocene $\delta^{18} \mathrm{O}$ records from ostracode valves provided evidence that the terminal Classic Maya collapse in the $9^{\text {th }}$ Century $\mathrm{AD}$ was related to drought in the lowland Neotropics (Hodell et al. 1995).

Tropical regions, including the Neotropics, serve as "heat engines", and as such, are critical areas for understanding past climate changes. The Yucatán Península of southern Mexico, northern Guatemala and Belize, is located in the northernmost Neotropics and consists of a karst platform with an altitude ranging between about 0 and $300 \mathrm{~m}$ a.s.1. (Ibarra-Manríquez et al. 2002; Perry et al. 2003; Rosenfeld 2002; Rosenmeier et al. 2002a; Schmitter-Soto et al. 2002; Suárez-Morales 2003). Lago Petén Itzá $\left(\mathrm{N} 17^{\circ} 00^{\prime}\right.$, W $\left.89^{\circ} 51^{\prime}\right)$, in the southern portion of the Yucatán Península, is part of the central Petén Lake District, Guatemala. Table 1 presents selected morphometric and limnological characteristics of this lake, which is a meso-oligotrophic karst water body, and 
Tab. 1. Principal morphometric and limnological characteristics of Lago Petén Itzá gathered from MARN-AMPI (2008), INSIVUMEH (personal communication), and this study. Reported data are from 2005 if not indicated otherwise. ${ }^{1)}$ From 1990-2003; ${ }^{2)}$ Determined in November 2005.

\begin{tabular}{|c|c|c|c|}
\hline \multicolumn{2}{|c|}{ Morphometric and limnological characteristics } & \multicolumn{2}{|c|}{$\begin{array}{l}\text { Physico-chemical variables from surface waters } \\
\text { above the deepest point }(160 \mathrm{~m})^{2)}\end{array}$} \\
\hline Longitude & $\mathrm{N} 17^{\circ} 00^{\prime}$ & Dissolved oxygen & $8.9 \mathrm{mg} \mathrm{L}^{-1}$ \\
\hline Latitude & W $89^{\circ} 51^{\prime}$ & $\mathrm{pH}$ & 8.5 \\
\hline Altitude & $120 \mathrm{~m}$ a.s.1 & Conductivity & $533 \mu \mathrm{S} \mathrm{cm}^{-1}$ \\
\hline Watershed area & $\sim 1064 \mathrm{~km}^{2}$ & $\mathrm{Ca}^{2+}$ & 2.9 meq L $^{-1}$ \\
\hline Lake area & $\sim 112 \mathrm{~km}^{2}$ & $\mathrm{Mg}^{2+}$ & $1.5 \mathrm{meq} \mathrm{L}^{-1}$ \\
\hline Lake volume & $8.5 \mathrm{~km}^{3}$ & $\mathrm{Na}^{+}$ & 0.5 meq $\mathrm{L}^{-1}$ \\
\hline Mean water depth & $76.2 \mathrm{~m}$ & $\mathrm{~K}^{+}$ & $0.1 \mathrm{meq}^{-1}$ \\
\hline Maximum water depth & $160 \mathrm{~m}$ & $\mathrm{SO}_{4}^{2-}$ & $3.3 \mathrm{meq} \mathrm{L}^{-1}$ \\
\hline Water transparency & $7.5 \mathrm{~m}$ & $\mathrm{HCO}_{3}^{-}$ & $1.9 \mathrm{meq} \mathrm{L}^{-1}$ \\
\hline Lake trophic status & meso-oligotrophic & $\mathrm{Cl}^{-}$ & 0.4 meq $\mathrm{L}^{-1}$ \\
\hline Location of thermocline & $\sim 20-40 \mathrm{~m}$ & Total ionic composition & $10.6 \mathrm{meq} \mathrm{L}^{-1}$ \\
\hline Averaged annual air temperature range ${ }^{1)}$ & $23.8-27.7^{\circ} \mathrm{C}$ & Total phosphorus & $9 \mu \mathrm{g} \mathrm{L}^{-1}$ \\
\hline Averaged annual air temperature & $27.2^{\circ} \mathrm{C}$ & Water temperature & $27.6^{\circ} \mathrm{C}$ \\
\hline Averaged annual precipitation & $\sim 1665 \mathrm{~mm}$ & $\delta^{18} \mathrm{O}$ lake water & $+2.9 \%$ \\
\hline Annual averaged relative humidity & $67.3 \%$ & $\delta^{13} \mathrm{C}$ lake water & $-5.2 \%$ \\
\hline
\end{tabular}

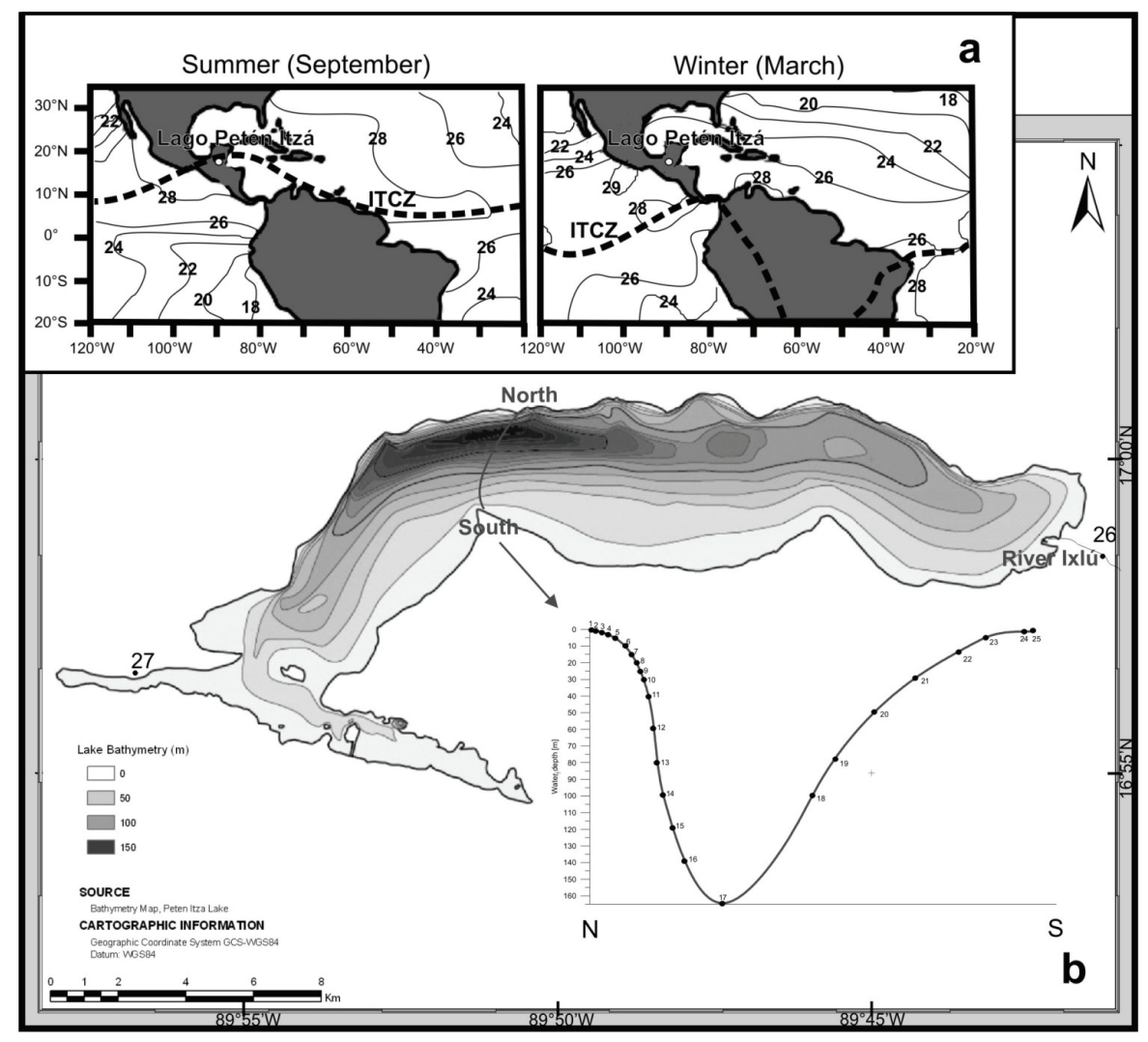

Fig. 1. a. Position of the Intertropical Convergence Zone (ITCZ) over the South American Continent. Dashed lines indicate the seasonal variation in the mean position of the ITCZ in summer and winter (modified from Haug et al. 2003). b. Study area, Lago Petén Itzá, located in northern Guatemala, showing the 27 sampling sites where surface sediment samples were retrieved.

the deepest in the Central American lowlands. Lago Petén Itzá, is $\sim 160 \mathrm{~m}$ deep and $\sim 100 \mathrm{~km}^{2}$ in area (Fig. 1b). The watershed covers an area of $\sim 1064 \mathrm{~km}^{2}$ (MARN-AMPI 2008). Owing to its great depth, Lago Petén Itzá, unlike most lakes on the Yucatán Península, never dried out during the last Glacial and deglacial, and has consequently yielded a complete sediment record spanning those time periods. Drilling operations in 2006 recovered cores spanning the past $>85$ kyrs (Hodell et al. 2006, 2008).

The region is characterized by relatively humid tropical climate. The minimum monthly mean air temperature in Flores, Petén, occurs in January $\left(22.3^{\circ} \mathrm{C}\right)$ and the maximum temperature is reached in May (29.8 $\left.{ }^{\circ} \mathrm{C}\right)$. Temperatures start to decrease in June, with the onset of seasonal summer rains. Evaporation is very low 
during the months of December and January (MARNAMPI 2008). Precipitation in the region depends on the seasonal migration of the Intertropical Convergence Zone (Haug et al. 2003, Fig. 1a) and ranges from 450 $\mathrm{mm} \mathrm{y}^{-1}$ on the northwest coast, to $2000 \mathrm{~mm} \mathrm{y}^{-1}$ on the southeastern part of the Yucatán Península (SchmitterSoto et al. 2002). Total annual rainfall in Flores in 2005 was $\sim 1665 \mathrm{~mm}$. The rainy season typically lasts from late May to December. Precipitation is highest in the months of June and September, averaging $\sim 215 \mathrm{~mm}$ (Pérez et al. 2008), but can be influenced strongly by individual tropical storms or hurricanes.

Overland inflow to Lago Petén Itzá is low due to fast infiltration of precipitation into ubiquitous calcrete aquifer layers (Perry et al. 2003). Remains of both ancient and $20^{\text {th }}$ Century construction in shallow waters near the present shoreline of Lago Petén Itzá illustrate that this lake experienced significant lake level changes, and that it responds rapidly to climate change.

Lakes in the region vary in their water chemistry as a result of climate, geology, topography and anthropogenic impact. Petén Itzá lake waters are dominated by calcium, bicarbonate, magnesium and sulfate, as it is typical of many karst lakes. Physical and chemical variables were measured in the lake in 1969 (Brezonik \& Fox 1974), 1976 (Deevey et al. 1980), 1985 (Basterrechea 1988), and 1993 (Curtis et al. 1998). There was an increase in ionic concentration over this sampling period. The volume of the lake and its water chemistry are sensitive to changes in precipitation and evaporation ratios that vary on seasonal to decadal timescales. Hillesheim et al. (2005) analyzed the oxygen isotopic composition of lake waters and precipitation in August 2002. Mean $\delta^{18} \mathrm{O}$ of lake waters was about $+2.9 \%$ and about $-4.0 \%$ for precipitation, indicating the strong influence of evaporation on the oxygen isotope signature of the lake water.

In conjunction with the drilling effort, a sampling campaign was carried out in Lago Petén Itzá and other lakes of the Yucatán Península in November 2005 and February 2008 to collect modern ostracode assemblages and limnological data. Our objective was to gather ecological information on modern ostracode species for a better interpretation of fossil assemblages from Petén Itzá sediment cores.

\section{METHODS}

\subsection{Collection and analysis of surface sediments, ostracodes and water samples}

The spatial distribution of ostracodes was studied along a north-south water depth transect across Lago Petén Itzá. In the northern part of the main basin of the lake, surface sediment samples were retrieved from the littoral zone $(0.5,2,3 \mathrm{~m})$ down to a depth of $160 \mathrm{~m}$. Samples were collected at intervals of $5 \mathrm{~m}$ to a water depth of $30 \mathrm{~m}$, and at $20 \mathrm{~m}$ intervals from $40 \mathrm{~m}$ to a depth of $160 \mathrm{~m}$. In the southern part of the main basin, samples were collected from the littoral zone $(0.1,0.7$ $\mathrm{m})$, and at water depths of 5, 15, 30, 50, 80 and $100 \mathrm{~m}$ (Fig. 1b). Twenty-seven surface sediment samples were collected at the end of the rainy season in November 2005. In February 2008, a littoral zone in the west and the Río Ixlú tributary in the east, were also sampled. Surface sediment samples along the N-S transect were retrieved with an Ekman grab attached to a $170 \mathrm{~m}$ long cable on an UWITEC hand winch. Littoral samples were taken in macrophyte beds with a special hand net (mesh size $250 \mu \mathrm{m}$ ). Sediment samples for ostracode analyses were preserved by adding $96 \%$ ethanol to reach a final concentration in surface sediments of $\sim 70 \%$. Water samples were collected with a Ruttner sampler at a site located over the deepest part of the lake. Samples were taken from the surface, at $5 \mathrm{~m}$ intervals to $20 \mathrm{~m}$, and at $20 \mathrm{~m}$ intervals down to a depth of $160 \mathrm{~m}$. Water transparency was measured with a Secchi Disc. Water samples for geochemical analyses were filtered with cellulose acetate $(\mathrm{CA})$ membrane filters $(0.2 \mu \mathrm{m})$, and then refrigerated. Lake waters were measured in situ for temperature, conductivity, $\mathrm{pH}$ and dissolved oxygen using a WTW Multi Set 350i. Bicarbonate $\left(\mathrm{HCO}_{3}^{-}\right)$was titrated immediately in the field with $0.1 \mathrm{~N} \mathrm{HCl}$ and the endpoint ( $\mathrm{pH} 4.3$ ) was read using methyl orange indicator. Duplicate water samples were collected for later analysis of elemental composition in the laboratory. Samples for cation measurement were preserved with $\mathrm{HNO}_{3}^{-}$. Both analyses for anions $\left(\mathrm{F}^{-}, \mathrm{Cl}^{-}, \mathrm{Br}^{-}, \mathrm{NO}_{3}^{-}\right.$, $\left.\mathrm{SO}_{4}^{-2}\right)$ and cations $\left(\mathrm{Sr}^{+2}, \mathrm{Ca}^{+2}, \mathrm{~K}^{+}, \mathrm{Mg}^{+2}, \mathrm{Na}^{+}\right)$took place in the Institute of Environmental Geology (IUG), University of Braunschweig. Anions and cations were determined, respectively, using Ion Chromatography with a 761 Compact IC Metrohm, and Inductively Coupled Plasma Optical Emission with an ICP-OES Jobin Yvon JY 50 P. Total phosphorus from samples conditioned with $\mathrm{H}_{2} \mathrm{SO}_{4}$ was determined in the Leibniz Institute of Freshwater Ecology and Inland Fisheries, Berlin. Water samples preserved with $\mathrm{CuSO}_{4}\left(500 \mathrm{mg} \mathrm{L}^{-1}\right)$ were analyzed for carbon and oxygen isotopes in the Department of Geological Sciences and Land Use and Environmental Change Institute (LUECI), University of Florida. Water samples for $\delta^{18} \mathrm{O}$ were measured using a VG/Micromass (now GV Instruments) PRISM Series II isotope ratio mass spectrometer. Oxygen isotopic results for waters are reported in delta notation relative to Standard Mean Ocean Water (VSMOW). Carbon isotopic ratios of DIC (Dissolved Inorganic Carbon) were measured with a Finnigan-MAT DeltaPlus XL isotope ratio mass spectrometer with a GasBench II universal on-line gas preparation device. Loss-on-ignition from surface sediments was determined after Heiri et al. (2001) at $550{ }^{\circ} \mathrm{C}$ and $950^{\circ} \mathrm{C}$, for the estimation of organic matter content and carbonate, respectively. Big shells of gastropods were removed from sediment samples to avoid their influence on carbonate content determination. Measurements were carried out in the IUG. 


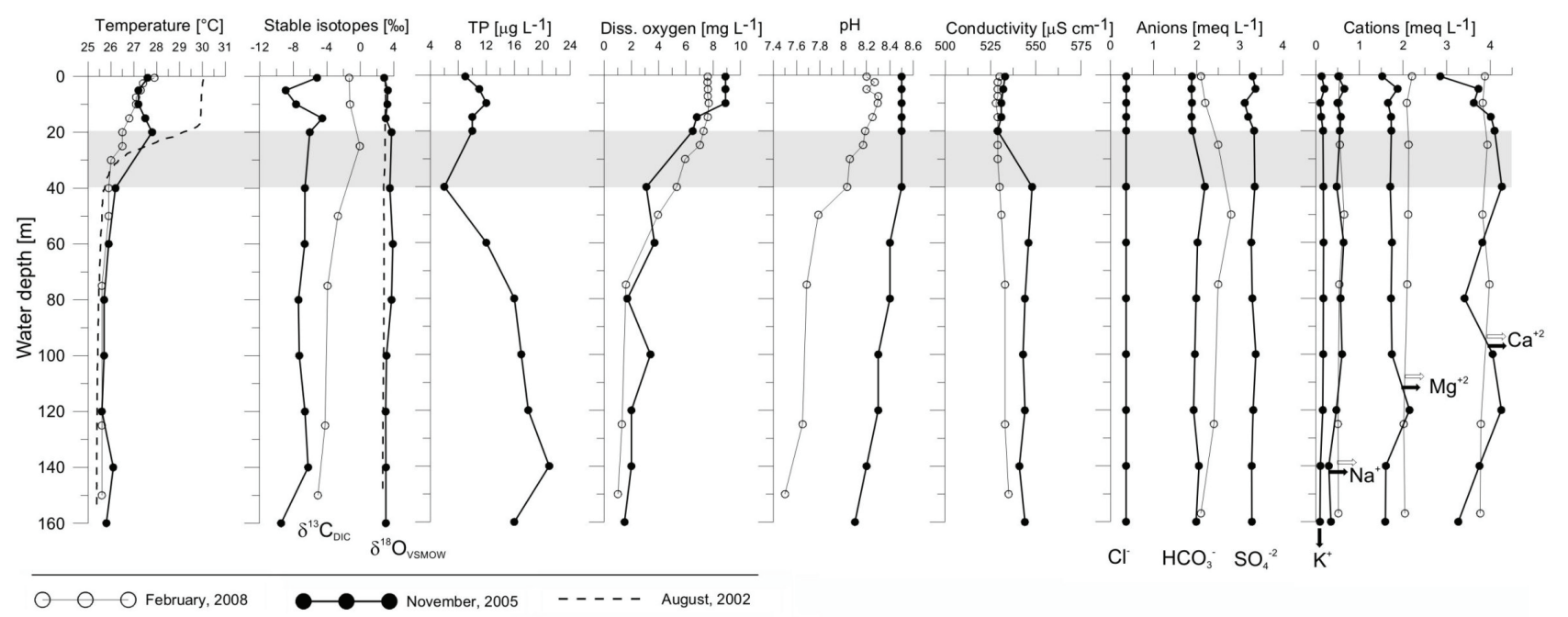

Fig. 2. Physical and chemical variables determined in a vertical water column profile at the deepest point of Lago Petén Itzá, Guatemala (November, 2005 and February, 2008). Grey bar at 20-40 m water depth indicates the location of the thermocline. Dashed lines show temperatures and $\delta^{18} \mathrm{O}$ values reported by Hillesheim et al. (2005) for August 2002.

\subsection{Ostracode distribution analysis}

For ecological analysis and interpretation, we used adult ostracodes with well-preserved valves and soft parts. We also distinguished between living individuals (carapaces with soft parts) and dead specimens (carapaces without soft parts). Ostracodes collected in 2005 were separated from sediment samples with fine brushes. Adult ostracode recovery was facilitated by wet-sieving surface samples with a $250 \mu \mathrm{m}$ mesh size, which removed clay and silts from samples. At least 5 $\mathrm{mL}$ of wet sediment was analyzed from each sample. Samples with $<100$ valves were analyzed completely. Species relative abundances were calculated as percentages in $50 \mathrm{~mL}$ of wet surface sediment. Ostracode species were identified using the taxonomic works of Brehm (1939), Furtos (1933, 1936a, b), Deevey et al. (1980), Pérez et al. (2009).

\subsection{Biodiversity indices, cluster analyses and correlations}

The Shannon Wiener Index "H" (Krebs 1989) was determined for the ostracode assemblages at each water depth to compare diversities, and the evenness index "E" (Magurran 1988) was calculated to evaluate the uniformity of species distributions in samples from different water depths. If the $\mathrm{E}$ value is 1, then individuals are evenly distributed among species in the sample. We used Renkonen's percent similarity index (Renkonen 1938), which is based on species relative abundance, to determine the similarity between samples. Surface samples with $<100$ valves in $50 \mathrm{~mL}$ of wet sediment, collected at 80 and $95 \mathrm{~m}$ water depth in the northern segment and at $80 \mathrm{~m}$ in the southern segment of the transect, and samples with low abundances of Cypretta brevisaepta?, and Candonocypris serratomarginata?, were excluded from the multivariate analyses on normalized data. Normalization of the data was achieved by dividing the mean by the standard deviation (x-mean/stdev). Cluster analysis (Ward's method, Euclidean distance) was used to define groups of water depths and of ostracode species based on their abundances. Ostracode species abundances were correlated with water depth, dissolved oxygen, and water temperature using Spearman's correlation. Other physico-chemical variables displayed only slight changes throughout the water column and thus were left out of this analysis. All analyses were done with the program PAST, version 1.89.

\section{RESULTS}

\subsection{Hydrochemistry}

Water transparency in Lago Petén Itzá was $7.5 \mathrm{~m}$ in November 2005, and $6.6 \mathrm{~m}$ in February 2008. Lake waters had an average total phosphorus (TP) concentration of $\sim 13 \mu \mathrm{g} \mathrm{L}^{-1}$ in November. Water column data (Fig. 2) from the deepest site in the lake suggest it is meso-oligotrophic. Water temperatures at $15 \mathrm{~m}$ water depth in November were $\sim 1^{\circ} \mathrm{C}$ higher than those measured in February. The vertical temperature profile reported by Hillesheim et al. (2005) for August 2002 shows higher epilimnetic temperatures, and a total decrease of $4.5^{\circ} \mathrm{C}$ in the metalimnion. Temperatures in August ranged from 30 to $25.4{ }^{\circ} \mathrm{C}$. The temperature range in November and February was smaller, from about 27.9 to $25.6{ }^{\circ} \mathrm{C}$. In both November and February, the thermocline was located between 20 and $40 \mathrm{~m}$ water depth, and temperatures in the hypolimnion ranged from 25.6 to $26.0{ }^{\circ} \mathrm{C}$. In November, water at 5 and $10 \mathrm{~m}$ depth had slightly lower temperatures $\left(27.2^{\circ} \mathrm{C}\right)$ than water at the surface and $20 \mathrm{~m}$ depth $\left(27.8^{\circ} \mathrm{C}\right)$. The carbon isotopic composition $\left(\delta^{13} \mathrm{C}\right)$ of the water column was more negative in November than in February. $\delta^{13} \mathrm{C}$ 
of dissolved inorganic carbon (DIC) ranged from -9.5 to $-4.6 \%$ in November, and from -5.1 to $-0.1 \%$ in February. $\delta^{13} \mathrm{C}$ values from 5 and $10 \mathrm{~m}$ water depth were more negative (-8.9 and $-7.7 \%$ ) in November than values at the surface and at $20 \mathrm{~m}(-6 \%) . \delta^{18} \mathrm{O}$ values in the water column displayed similar values top to bottom and were fairly stable across seasons. The oxygen isotopic composition in November 2005 averaged $+3.3 \%$, ranging only from +2.9 to $+3.9 \%$, and in August 2002, averaged $+2.9 \%$ o $(+2.7$ to $+3.0 \%$ ). Total phosphorus concentrations in the vertical profile ranged from 6 to $21 \mu \mathrm{g} \mathrm{L}^{-1}$, with highest values in the hypolimnion.

Dissolved oxygen concentration in surface waters was $8.9 \mathrm{mg} \mathrm{L}^{-1}$ in November, while bottom waters contained only $\sim 1.25 \mathrm{mg} \mathrm{L}^{-1}$. Surface waters displayed a $\mathrm{pH}$ range of 8.2-8.5. The lowest value (7.5) was measured in February 2008 in deep waters of the lake $(\sim 150 \mathrm{~m})$, and probably reflects the presence of abundant respiratory $\mathrm{CO}_{2}$. Conductivity in November ranged from 529 to $544 \mu \mathrm{S} \mathrm{cm}^{-1}$, and 528 to $535 \mu \mathrm{S} \mathrm{cm}^{-1}$ in February. Conductivity increased slightly with water depth. Salinity was $0.2 \%$. The total ion concentration at the surface was $\sim 10.6 \mathrm{meq} \mathrm{L}{ }^{-1}$. Sulfate and bicarbonate were the dominant anions, and calcium and magnesium were the dominant cations. Concentrations of cations were very similar in November 2005 and February 2008. $\mathrm{Cl}^{-}, \mathrm{Na}^{+}$, and $\mathrm{K}^{+}$were present in relatively low concentrations $\left(<0.7 \mathrm{meq} \mathrm{L}^{-1}\right)$. Chloride concentration in all water samples was $0.4 \mathrm{meq} \mathrm{L}^{-1}$. Sulfate concentration ranged between 3.1 and 3.4 meq $\mathrm{L}^{-1}$ and $\mathrm{HCO}_{3}^{-}$between 1.9 and $2.2 \mathrm{meq} \mathrm{L}^{-1}$. Maximum concentrations of cations occurred in November 2005: calcium (4.3 meq $\left.\mathrm{L}^{-1}\right)$, potassium $\left(0.2 \mathrm{meq} \mathrm{L}^{-1}\right)$, magnesium $\left(2.1 \mathrm{meq} \mathrm{L}^{-1}\right)$, and sodium $\left(0.7 \mathrm{meq} \mathrm{L}^{-1}\right)$. The minimum concentrations in that year were: calcium $\left(2.9 \mathrm{meq} \mathrm{L}^{-1}\right)$, potassium $(0.1$ meq $\left.\mathrm{L}^{-1}\right)$, magnesium $\left(1.5\right.$ meq $\left.\mathrm{L}^{-1}\right)$, and sodium $(0.3$ meq $\left.L^{-1}\right)$.

\subsection{Ostracode species assemblages of Lago Petén Itzá across the north-south water depth transect}

Eleven ostracode species were identified in surface sediments from the N-S transect, the littoral zone in the west of Lago Petén Itzá, and in the Río Ixlú tributary (Tab. 2). For details regarding taxonomy, Scanning Electron Microscope (SEM) and Light Microscope photographs of taxa, see Pérez et al. (2009).

\subsubsection{Species richness, diversity and abundances}

Figure 3 shows species assemblages, species relative abundances, and biodiversity indices along the northsouth transect in Lago Petén Itzá. Relative abundances (\%) of carapaces with and without soft parts, and valves from adult ostracodes are presented. Maximum species richness on the south end of the transect was eight, and on the north end seven. The Shannon Wiener Index ranged in the northern transect segment from 0.24 to 1.59 , and in the southern transect segment from 0.74 to
1.84 (Fig. 3). The highest diversities were found at water depths of $0.7 \mathrm{~m} \mathrm{(1.63)}$ and $30 \mathrm{~m}(1.84)$ in the southern part of the lake, and the lowest at $2 \mathrm{~m}(0.24)$ in the northern part of the lake. The Evenness Index ranged on the northern transect segment from 0.13 to 0.98 and on the southern segment from 0.27 to 0.95 . The lowest Evenness Index was determined on samples taken at a water depth of $50 \mathrm{~m}$ in the south and at $2 \mathrm{~m}$ in the north. The Renkonen similarity percentage correlates well with the dominance of $P$. globula. The lowest Renkonen percentage in the northern transect segment was $30.4 \%$, corresponding to a water depth of $100 \mathrm{~m}$, and $34.5 \%$ at $5 \mathrm{~m}$. The lowest percentage in the south was $31.5 \%$ at a water depth of $50 \mathrm{~m}$. The highest percentages ( 91.7 and $90.4 \%$ ) were found at 30 and $20 \mathrm{~m}$ water depth, respectively, on the northern transect.

The dominant species in the lake are $P$. globula and C. okeechobei, followed by L. opesta, C. ilosvayi and Pseudocandona sp. Strandesia intrepida, H. punctata, and D. stevensoni are less common. Cypridopsis okeechobei showed the highest number of living ostracodes (502 individuals at $3 \mathrm{~m}$ water depth on the northern transect), followed by $L$. opesta (214 individuals in the littoral zone of the northern transect) and P. globula (101 individuals at $5 \mathrm{~m}$ on the southern transect). Cytheridella ilosvayi, D. stevensoni, and Pseudocandona sp. were generally represented by valves rather than living specimens.

Tab. 2. Modern ostracode fauna of Lago Petén Itzá, Guatemala.

\begin{tabular}{l}
\hline Crustacea \\
Ostracoda \\
Candonidae Kaufmann, 1900 \\
Physocypria globula Furtos, 1933 \\
Pseudocandona sp. \\
Cyprididae Baird, 1845 \\
Candonocypris serratomarginata? (Furtos, 1936) \\
Cypretta brevisaepta? Furtos, 1934 \\
Cypridopsis okeechobei Furtos, 1936 \\
Heterocypris punctata Keyser, 1976 \\
Stenocypris major (Baird, 1859) \\
Strandesia intrepida Furtos, 1936 \\
Darwinulidae Brady \& Norman, 1889 \\
Darwinula stevensoni (Brady \& Robertson, 1870) \\
Limnocytheridae Klie, 1938 \\
Cytheridella ilosvayi Daday, 1905 \\
Limnocythere opesta Brehm, 1939
\end{tabular}

3.2.2. Grouping of ostracode assemblages based on species assemblages at various water depth ranges

Analysis of the ostracode distribution, diversity, and abundance allowed classification of three main water depth ranges in Lago Petén Itzá: littoral zone (0.1-3 m), above and at the thermocline $(\leq 40 \mathrm{~m})$, and below the thermocline $(>40 \mathrm{~m})$. Two dendrograms (Figs $4 \mathrm{a}, \mathrm{b}$ ) show the relationship between ostracode abundances and water depth. Figure 4 a classifies all sampled water depths into 5 groups and three main water depth ranges: 


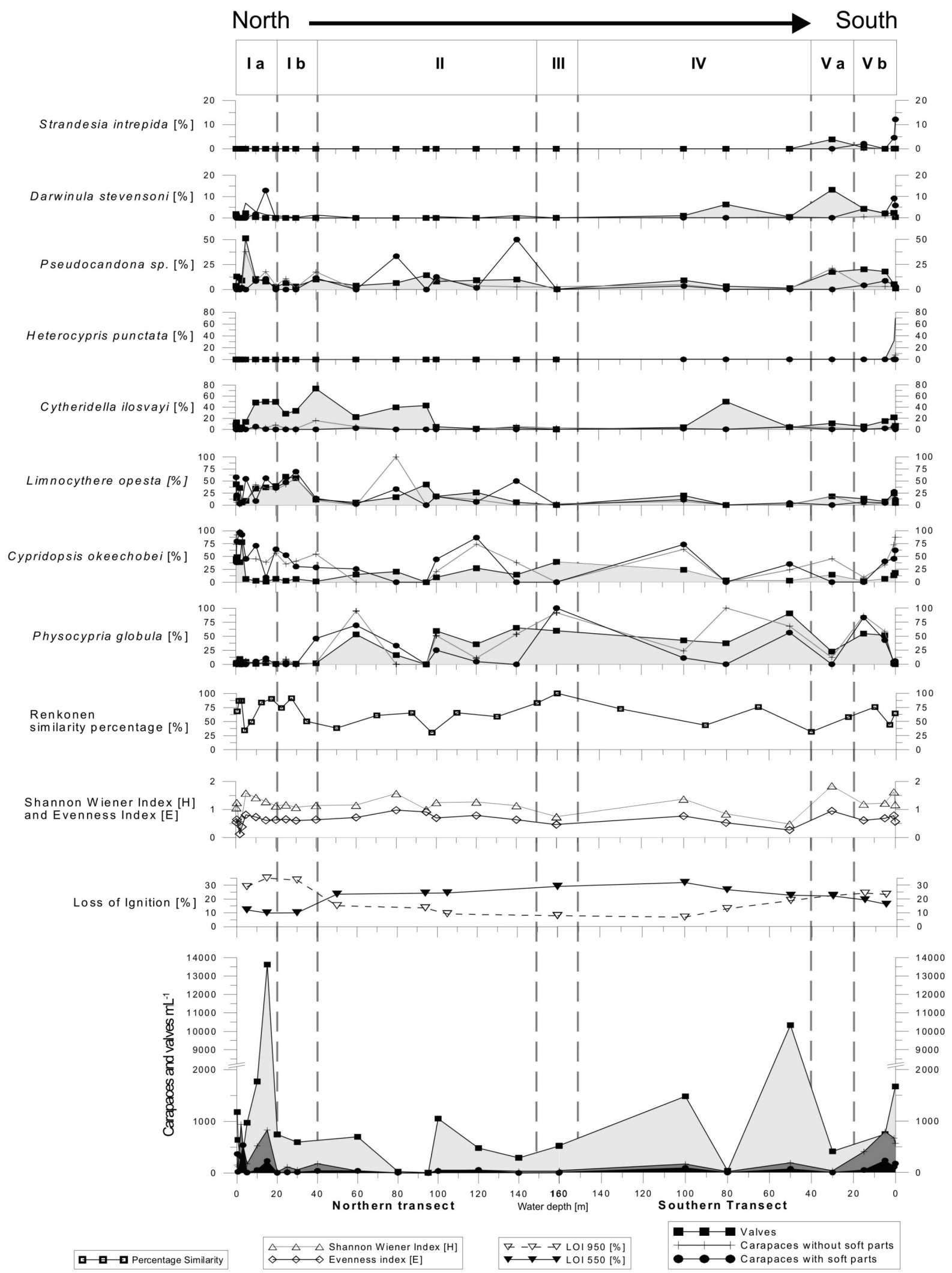

Fig. 3. Modern ostracode species assemblages (adult valves, carapaces with and without soft parts) from surface sediments collected in 2005 across a north-south transect in Lago Petén Itzá. Species relative abundance, biodiversity indices, and loss on ignition are shown. The light grey shading in the bottom graph indicates the number of valves; grey, carapaces without soft parts; and black, carapaces with soft parts in $50 \mathrm{~mL}$ of wet sediment. 


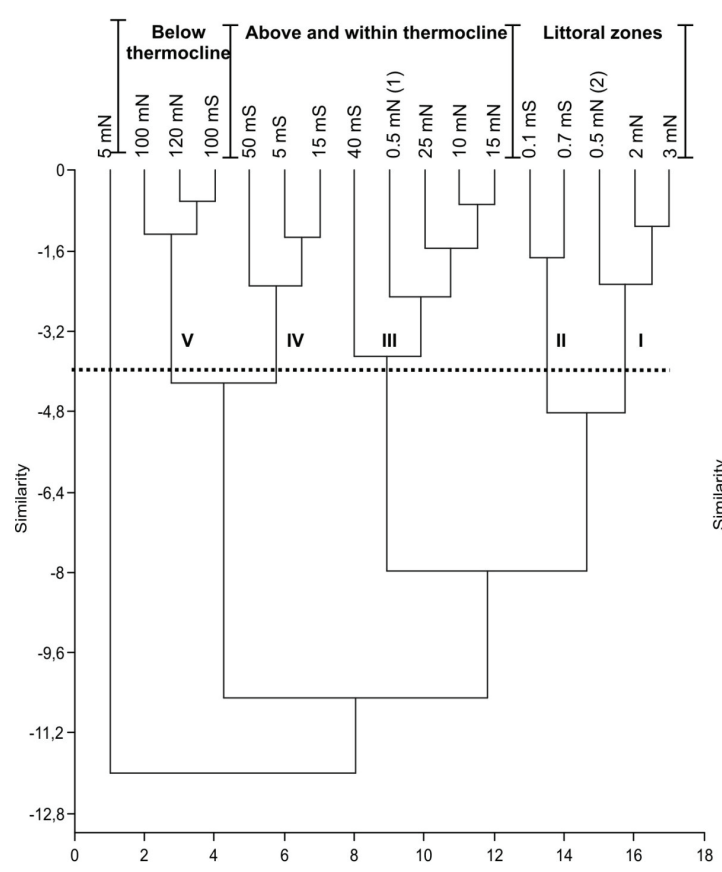

b

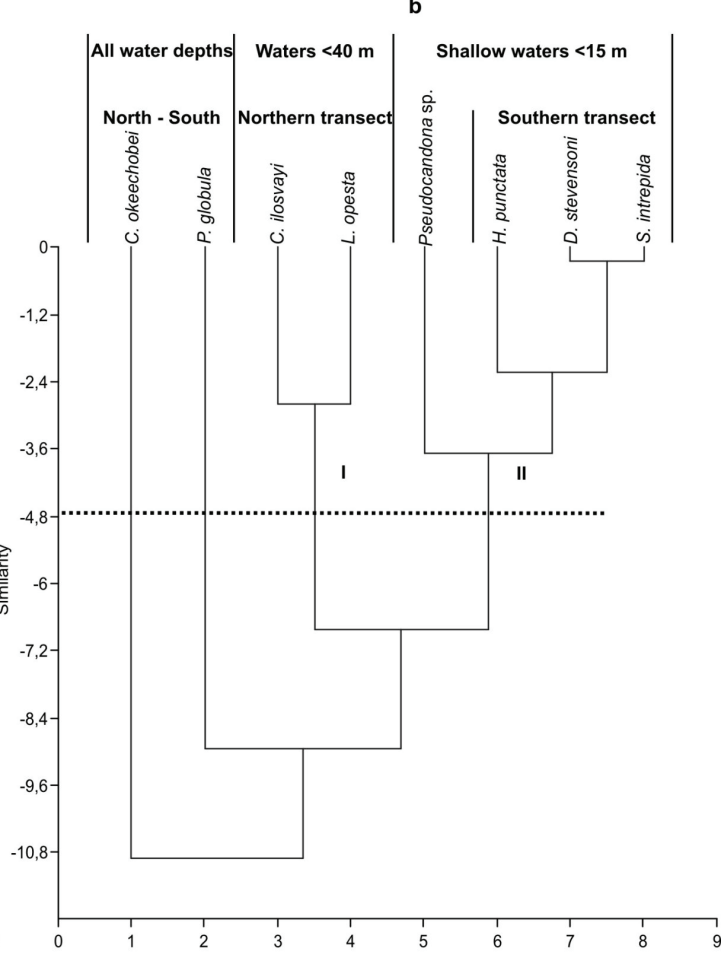

Fig. 4. Dendrograms of two cluster analyses using Ward's method. Dashed line shows the cut-off criterion for cluster partitioning. a. Cluster analysis based on water depths in a north-south transect, indicating the three groups of water depths based on species relative abundances in Lago Petén Itzá (1) littoral zones, (2) depths above, at the thermocline, and (3) below the thermocline; b. Cluster analysis showing species three main associations and ostracode water-depth preferences: (1) water depths $<40 \mathrm{~m}$, (2) shallow waters $<15 \mathrm{~m},(3)$ and water depths $>40 \mathrm{~m}$.

\section{(1) Littoral zone (0.1-3 m)}

Groups I and II in the cluster analysis (Fig. 4a) consist only of depths in the littoral zone from 0.1 to $3 \mathrm{~m}$, where temperature $\left(27.6{ }^{\circ} \mathrm{C}\right)$ and the dissolved oxygen concentration $\left(8.9 \mathrm{mg} \mathrm{L}^{-1}\right)$ reach maxima. There, macrophyte cover, consisting mainly of Typha dominguensis, Vallinesneria americana and Potamogeton sp., was higher than at other water depths. Ostracode carapaces were more abundant from the littoral zone to a water depth of $20 \mathrm{~m}$ (Sections Ia, and Vb, Fig. 3). Carapaces lacking soft parts were most abundant (943 carapaces $50 \mathrm{~mL}^{-1}$ ) at a water depth of $2 \mathrm{~m}$ along the northern shore of the lake, and carapaces containing well preserved soft parts $\left(541\right.$ carapaces $\left.50 \mathrm{~mL}^{-1}\right)$ were mostly collected at $3 \mathrm{~m}$ water depth, also in the north (Section Ia, Fig. 3).

\section{(2) Above and at the thermocline $(\leq 40 \mathrm{~m})$}

Groups III and IV (Fig. 4a) comprise water depths from the littoral zone to $40-50 \mathrm{~m}$, i.e. from the base of the littoral zone to the base of the thermocline. Compared with surface waters, these deeper water depths are characterized by decreases in dissolved oxygen concentration of $\sim 5 \mathrm{mg} \mathrm{L}^{-1}$ and a temperature reduction of $\sim 1.7$ ${ }^{\circ} \mathrm{C}$. From 20 to $40 \mathrm{~m}$ (Sections Ib, Va, Fig. 3) abundances decreased. These depths, i.e. $20-40 \mathrm{~m}$, define the position of the thermocline (Fig. 2). The highest number of valves in the N-S transect $\left(13,623\right.$ valves $\left.50 \mathrm{~mL}^{-1}\right)$ was found at a water depth of $15 \mathrm{~m}$ near the northern shore of the lake (Section Ia, Fig. 3). There, C. ilosvayi and $L$. opesta were the dominant species.

(3) Below the thermocline ( $>40 \mathrm{~m}$ )

Group V (Fig. 4a) includes depths from 100-160 m, well below the thermocline. Here, conductivity is only slightly higher $\left(544 \mu \mathrm{S} \mathrm{cm} \mathrm{cm}^{-1}\right)$ than in shallower water depths $\left(533 \mu \mathrm{S} \mathrm{cm}^{-1}\right)$, but oxygen content is low $(1 \mathrm{mg}$ $\left.\mathrm{L}^{-1}\right)$ and temperatures reach minimum values $\left(25.6^{\circ} \mathrm{C}\right)$. Fewer carapaces with and without soft parts were usually found below $40 \mathrm{~m}$ depth (Sections II, III, IV, Fig. 3 ), but the highest number of valves along the southern part of the transect $\left(10,845\right.$ valves $\left.50 \mathrm{~mL}^{-1}\right)$ was found at $50 \mathrm{~m}$ water depth (Section IV, Fig. 3).

The second dendrogram of the cluster analysis (Fig. 4b) classifies the species into two groups and three species associations based on their spatial distribution: 1) Cytheridella-Limnocythere-Cypridopsis (Group I): Cytheridella ilosvayi and Limnocythere opesta are benthic species that live at a maximum water depth of $\sim 40$ $\mathrm{m}$ and are more abundant in shallow waters $(<20 \mathrm{~m})$ of the northern transect segment. Living specimens of $L$. opesta dominated primarily in waters $<40 \mathrm{~m}$, and specimens of C. ilosvayi were scarce in the lake. Cypri- 
Tab. 3. Spearman's correlation between species abundance, dissolved oxygen and temperature in lake waters. Variables with a high correlation (+/- 0.7-1.0) are shown in bold underlined numbers. Bold numbers indicate a correlation between 0.6-0.7. Correlation values are shown in the lower triangle and the probabilities in the upper triangle of the matrix. Diss. O: Dissolved oxygen; Cond.: Conductivity; Temp.: Temperature; C. okee: C. okeechobei; C. ilos: C. ilosvayi; D. stev: D. stevensoni; Pseudo. sp.: Pseudocandona sp.; H. punc: Heterocypris punctata; L. opes: L. opesta; P. glo: P. globula; S. intre: $S$. intrepida.

\begin{tabular}{|c|c|c|c|c|c|c|c|c|c|c|c|}
\hline & Depth & Diss. O & Temp. & C. okee & C. ilos & D. stev & Pseudo. sp. & H. punc & L. opes & P. glo & S. intre \\
\hline Depth & & 0.00 & 0.00 & 0.07 & 0.60 & 0.13 & 0.72 & 0.03 & 0.69 & 0.00 & 0.00 \\
\hline Diss. O & $\underline{-0.96}$ & & 0.00 & 0.09 & 0.56 & 0.10 & 0.96 & 0.12 & 0.73 & 0.00 & 0.00 \\
\hline Temp. & $\overline{-0.89}$ & $\underline{0.84}$ & & 0.24 & 0.37 & 0.14 & 0.51 & 0.10 & 0.50 & 0.00 & 0.00 \\
\hline C. okee & $\overline{-0.39}$ & $\overline{0.36}$ & 0.26 & & 0.00 & 0.12 & 0.12 & 0.23 & 0.25 & 0.07 & 0.10 \\
\hline C. ilos & -0.12 & 0.13 & 0.20 & -0.59 & & 0.02 & 0.11 & 0.80 & 0.00 & 0.24 & 0.89 \\
\hline D. stev & -0.32 & 0.35 & 0.32 & -0.33 & 0.49 & & 0.00 & 0.30 & 0.25 & 0.93 & 0.04 \\
\hline Pseudo. sp & 0.08 & -0.01 & -0.14 & -0.33 & 0.34 & 0.68 & & 0.19 & 0.26 & 0.29 & 0.15 \\
\hline H. punc & -0.44 & 0.34 & 0.35 & 0.26 & -0.06 & 0.23 & -0.28 & & 0.71 & 0.23 & 0.20 \\
\hline L. opes & -0.09 & 0.08 & 0.15 & -0.25 & 0.57 & 0.25 & 0.24 & -0.08 & & 0.05 & 0.99 \\
\hline P. glob & 0.65 & -0.60 & $\underline{-0.71}$ & -0.39 & -0.25 & -0.02 & 0.23 & -0.26 & -0.42 & & 0.07 \\
\hline S. intre & $\underline{-0.73}$ & $\underline{0.71}$ & $\overline{0.61}$ & 0.35 & -0.03 & 0.44 & 0.31 & 0.28 & 0.00 & -0.38 & \\
\hline
\end{tabular}

dopsis okeechobei is nektobenthonic and is the dominant species in the littoral zone where there is abundant vegetation; 2) Pseudocandona-Heterocypris-DarwinulaStrandesia (Group II): Pseudocandona sp., H. punctata, $D$. stevensoni and $S$. intrepida inhabit primarily shallow waters $(\leq 15 \mathrm{~m})$. Pseudocandona sp. prefers water depths between 5 and $15 \mathrm{~m}$ in the northern segment of the transect. Few living specimens of Pseudocandona sp. and D. stevensoni were found in water depths $<15$ $\mathrm{m}$. D. stevensoni and S. intrepida were more abundant in the southern transect segment and were also abundant at a water depth of $15 \mathrm{~m}$. H. punctata was found at a maximum water depth of $\sim 1 \mathrm{~m}$ in the southern transect; 3) Physocypria: Unlike other species, $P$. globula was found at almost all water depths. Living specimens of $P$. globula were the dominant taxon at water depths between 50 and $60 \mathrm{~m}$.

\subsection{Ostracode abundances related to water depth and associated variables}

The number of ostracodes correlates positively with the carbonate concentration in sediments. Carbonate content in the sediment displays highest concentrations in the lake littoral zone (23.3\%), down to a water depth

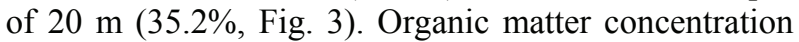
in sediment increases at $\sim 20 \mathrm{~m} \mathrm{(22 \% )}$ and reaches highest values at $100 \mathrm{~m} \mathrm{(31.9 \% )} \mathrm{and} 160 \mathrm{~m} \mathrm{(29.1 \% ).} \mathrm{Few}$ ostracodes were encountered in these organic-rich deposits. Shallow waters down to $20 \mathrm{~m}$ depth are characterized by low amounts of clay and high quantities of silt. Sediments from deeper waters are composed of higher amounts of clay and lower amounts of silt.

We used simple correlation to explore relationships among ostracode abundances, water depth, temperature, and oxygen concentration (Tab. 3). Water depth is negatively correlated with oxygen concentration $(r=$ -0.96), temperature $(r=-0.89)$, and with the abundance of Strandesia intrepida $(r=-0.73)$. Physocypria globula displays a positive correlation with water depth $(r=$ $0.65)$. Dissolved oxygen showed a relatively strong positive correlation with temperature $(r=0.84)$ and with the abundance of $S$. intrepida $(r=0.71)$. Water temperature is negatively correlated with abundance of Physocypria globula $(r=-0.71)$ and positively correlated with abundance of $S$. intrepida $(r=0.61)$. Darwinula stevensoni showed a positive correlation of 0.68 with Pseudocandona sp.

\section{DISCUSSION}

An understanding of modern physico-chemical requirements of ostracode species is important for interpreting the paleoenvironmental significance of ostracode fossil assemblages. This study provides some of the first ecological information necessary for using ostracodes as indicators of past climate and environmental changes in the lowland Neotropics.

\subsection{Physical and chemical characteristics of lake waters}

Lago Petén Itzá was thermally stratified at the end of the rainy season in 2005 (November), and during the dry season in 2008 (February). Stable stratification was also reported from July 1969 (Brezonik \& Fox 1974), and August 2002 (Hillesheim et al. 2005). The thermocline is located between $\sim 20$ and $\sim 40$ m water depth (Brezonik \& Fox 1974; Basterrechea 1988; Hillesheim et al. 2005). Brezonik \& Fox (1974), and Basterrechea (1988) attribute the stable stratification in Lago Petén Itzá to the large density difference per degree change in temperature in warm waters, lake basin morphometry, and high relief along the north shore, which provides wind protection. Thermal profiles measured in 1980 (Brenner \& Binford, unpublished data) close to the north-shore village of San Andrés ( $40 \mathrm{~m}$ water depth), showed the thermocline located between 10 and $20 \mathrm{~m}$ water depth from June to August. This highlights the importance of measuring vertical temperature profiles at different water depths throughout the lake.

$\delta{ }^{13} \mathrm{C}$ values of DIC were more negative in November 2005 than in February 2008, suggesting less primary 
productivity and lower phytoplankton concentrations in November than in February. Secchi disc transparency in November was greater $(7.5 \mathrm{~m})$ than in February $(6.6 \mathrm{~m})$, suggesting lower plankton concentrations in November. Secchi disc transparency in November and February was $\sim 2-2.5 \mathrm{~m}$ greater than values reported by Brezonik \& Fox (1974) and Basterrechea (1988). Water transparency in the lake is determined largely by turbidity, which is mostly associated with plankton density. Temperatures in June and July are higher than in November and February and nutrient concentrations are probably higher in the rainy season. Thus, plankton concentrations in summer are higher and Secchi disc transparency is lower. Turbidity may also increase during the rainy season (May-December) because of higher surface runoff, which carries abundant suspended material. Although evaporation is normally lower in November than in August, higher input of precipitation in August with more negative isotopic values $\left(\delta^{18}\right.$ OSMOW: $-4.0 \%$, Hillesheim et al. 2005), might explain why the mean $\delta^{18} \mathrm{O}$ value $(3.3 \%$ ) of waters we collected in November 2005 was higher than those reported for August (2.9\%) by Hillesheim et al. (2005).

The dominant cation in lake waters is calcium and the dominant anion is sulfate. Basterrechea (1988) pointed out that magnesium concentrations in the lake decreased after 1974 and suggested that an increase of calcium could be related to a reduction in groundwater outflow, also leading to higher lake levels. Lago Petén Itzá, however, still lacks a quantitative hydrologic budget.

\subsection{Ostracode distribution and diversity along a water depth gradient}

The distribution and abundance of ostracode species in Lago Petén Itzá is related to water depth and associated variables temperature, dissolved oxygen, carbonate and organic matter content in the sediments, and sediment type. The carbonate content in sediments is positively correlated with the abundance of ostracodes in part because we did not remove ostracode valves from sediments. Only large gastropod shells were removed. Külköylüoğlu (2005) and Yılmaz \& Külköylüoğlu (2006) reported temperature and dissolved oxygen as the most important influences on ostracode species assemblages. Other critical variables that can affect ostracode distribution are altitude, air temperature, degree of organic pollution, water flow velocity, water chemical composition, and water depth (King et al. 1996; Mezquita et al. 1996, 1999; Frenzel et al. 2009). Ostracodes are not directly influenced by water depth (Wrozyna et al. 2009). Instead, changes in physical and chemical variables and type of substrate associated with water depth influence the ostracode species composition. Temperature, $\mathrm{pH}$, dissolved oxygen concentration, species richness and abundances all decrease in the metalimnion (20-40 m). Ostracodes mostly inhabit waters $<20 \mathrm{~m}$ because deeper waters $(>75 \mathrm{~m})$ are low in oxygen, and sediments are rich in organic matter and poor in carbonates. Waters $<20 \mathrm{~m}$ depth contain more plants, which provide ostracodes with protection against predation. Plant epiphyton provides ostracodes with food. Müller et al. (2009) identified a "shallow-water zone" in Lago Petén Itzá extending to $23 \mathrm{~m}$ water depth, with a high abundance and diversity of gastropods. They also defined a "deep-water zone" (23-160 m), characterized by few gastropods. Gastropod and ostracode distribution and diversity are controlled mainly by the position of the thermocline in the lake and lithologic composition of the sediment, thus accounting for the correlation between species abundances and water depth.

Ostracodes are more abundant on the northern side of the lake, but species richness is slightly higher in the south, perhaps reflecting differences in lake morphology. The northern basin is very steep, causing sediment resuspension and redeposition, while the southern basin is much shallower, and possesses seasonal swamps at the edge (Hillesheim et al. 2005). The southern part of the lake is characterized by more extensive macrophyte cover and calmer waters. Species preferring such environments are D. stevensoni, $S$. intrepida and $H$. punctata. Cytheridella ilosvayi, C. okeechobei and L. opesta prefer environments in the northern segment of the transect. Physocypria globula has a wide distribution in Lago Petén Itzá. According to Deevey et al. (1980), this species is one of the few non-marine planktonic ostracode species in the world. In their study, they discovered that this species is actually part of the zooplankton and thus truly planktonic. We only analyzed surface sediments and did not retrieve Schindler-trap samples for zooplankton as did Deevey et al. (1980). We occasionally found ostracode carapaces of "living" specimens in deep waters $(50-60 \mathrm{~m})$. This might indicate that the species tolerates low oxygen concentrations $(\sim 3 \mathrm{mg}$ $\mathrm{L}^{-1}$ ) in waters, or that ostracodes that inhabit more oxygenated waters may have died and been carried to deep sites by currents. In such cases, physico-chemical variables at the collection site may not be truly indicative of the ostracode's preferred environment. Ability to reside in deep waters may be a means to avoid predation by fish (Deevey et al. 1980). In a study of vertical migration of $P$. globula (which they mistakenly identified as Cypria petenensis) in Laguna de Yaxhá ( $25 \mathrm{~m}$ water depth), Deevey et al. (1980) found that adult specimens avoided the upper $\sim 2 \mathrm{~m}$ of the water column during daylight hours, but could be found at depths with little dissolved oxygen, consistent with our observations. Our results show a positive correlation between $P$. globula and organic matter concentration (Fig. 3). As noted above, we sometimes found carapaces with soft parts of $P$. globula in deep waters, which probably corresponded to ostracodes that were transported to these deep-water, organic-rich sediments after death. Strandesia intrepida 
showed a relatively strong negative correlation with water depth $(r=-0.73)$ and positive correlations with temperature $(r=0.61)$ and dissolved oxygen $(r=0.71)$. This indicates that the distribution of this species is probably determined by a combination of these related factors. It requires warm temperatures $\left(>27{ }^{\circ} \mathrm{C}\right)$ and high concentrations of dissolved oxygen $\left(>7 \mathrm{mg} \mathrm{L}^{-1}\right)$.

We determined the number of whole carapaces at each sampling site, as this might be indicative of postmortem transportation. High numbers of intact carapaces would indicate low or no post-mortem transport and rapid burial (Whatley 1988), which is the case in the littoral zone and waters $<15 \mathrm{~m}$ of Lago Petén Itzá. The amount of carapaces, however, might also depend on the type of hinge, or solution used when preserving ostracodes, i.e. alcohol. We found the highest number of valves across the N-S transect at a water depth of $15 \mathrm{~m}$ on the northern side of the lake. Cytheridella ilosvayi and L. opesta were the dominant species there. Nevertheless, close to this sampling site, at $2 \mathrm{~m}$ water depth, fewer valves were encountered. The Renkonen similarity index, which compares ostracode abundances among samples, yielded a low value for samples from 2 and 15 $\mathrm{m}$ water depth, which is related to low abundance of valves in $2 \mathrm{~m}$ of water. We suspect that valves $2 \mathrm{~m}$ water depth were transported to the site at $15 \mathrm{~m}$. The Renkonen index was also low (30.3\%) when we compared ostracode abundances from samples retrieved at 95 and $100 \mathrm{~m}$. The number of valves in samples from these water depths was very low ( $<44$ valves), and we again suspect that valves from these water depths were transported from these areas to even deeper sites. Other sediment redeposition sites were identified at 50 and $100 \mathrm{~m}$ water depth in the southern part of the lake, where ostracode valve concentrations were relatively high. Anselmetti et al. (2006) indicated that at water depths from 20 to $35 \mathrm{~m}$ in the metalimnion erosion/nondeposition processes occur, perhaps related to currents. Ostracode analyses of this sort have been used to provide evidence of sediment redeposition (Whatley 1988; Frenzel \& Boomer 2005). In our study, the highest numbers of living adult ostracodes, i.e. carapaces with soft parts, corresponded to L. opesta and C. okeechobei. It is possible that other species were experiencing recruitment when we sampled in November and February, and that juveniles were more abundant than adults during those months. This highlights the importance of collecting ostracodes during different seasons, so that it is possible to assess adult/juvenile ratios, and understand taphonomic features and reproductive patterns (Cohen \& Morin 1990; Palacios-Fest et al. 2001; Parker et al. 2003). There is still a need to study ostracode life histories in Lago Petén Itzá and determine which environmental variables (e.g., changes in precipitation, salinity, etc.) trigger hatching (De Deckker 1983). Additional studies about ostracode communities will provide a better understanding of ostracode ecology. No living specimens and only single valves from Cypretta brevisaepta? were collected at a water depth of $15 \mathrm{~m}$ on the northern part of the transect, indicating their presence in the lake. This species may be largely restricted to areas we did not sample, and future studies should attempt to collect specimens in other parts of the lake. We sampled only three littoral locations (north, south and west) at two times (November and February). More intensive spatial and temporal sampling might yield species we failed to collect.

\subsection{Ostracode ecological preferences and implications for paleoenvironmental reconstructions}

The most important ecological preferences of each species and their implications for paleoenvironmental reconstructions are listed in table 4 . Species that primarily live in shallow waters $(<1 \mathrm{~m})$ are: Candonocypris serratomarginata?, Heterocypris punctata, and Stenocypris major. Strandesia intrepida lives from the littoral zone to a water depth of $15 \mathrm{~m}$. S. intrepida and $H$. punctata inhabit only the littoral zone, living among abundant aquatic macrophytes. Species living at a maximum water depth of $20 \mathrm{~m}$ are Cypretta brevisaepta?, Cytheridella ilosvayi, Darwinula stevensoni, and Pseudocandona sp. Living specimens of Limnocythere opesta were found from the littoral zone to a maximum water depth of $40 \mathrm{~m}$. Cypridopsis okeechobei and Physocypria globula were found at almost all water depths. Cypridopsis okeechobei is a nektobenthonic species and is more abundant in the littoral zone. Physocypria globula is planktonic and the dominant species in deeper water depths $(50-60 \mathrm{~m})$. One important implication for paleoenvironmental reconstruction is that $L$. opesta appears to mark the position of the thermocline. Physocypria globula indicates deep waters. Cypridopsis okeechobei and P. globula display broad hydrochemical tolerance, and their exclusive presence in a sediment sample could indicate environments that are stressful for other species.

\section{CONCLUSIONS}

Our study shows that the distribution of ostracodes in Lago Petén Itzá, Guatemala, is influenced by the physico-chemical characteristics of the water column and surface sediments. Characteristics such as water depth, temperature, dissolved oxygen concentration, and sediment type, influence the distribution and abundance of eleven ostracode species in the lake. Ostracodes from Lago Petén Itzá sediment cores thus have high potential as indicators of lake level changes. Highest abundance and diversity are found in the littoral zone and in shallow waters down to a depth of $20 \mathrm{~m}$. The thermocline is located between 20 and $40 \mathrm{~m}$ water depth, and deeper waters $(>40 \mathrm{~m})$ hosted few living ostracodes.

Ostracodes from Lago Petén Itzá can be used for the reconstruction of lake level changes because their distribution can be grouped by depth: 
Tab. 4. Most important ecological preferences of Lago Petén Itzá's ostracodes and their application for paleoreconstructions.

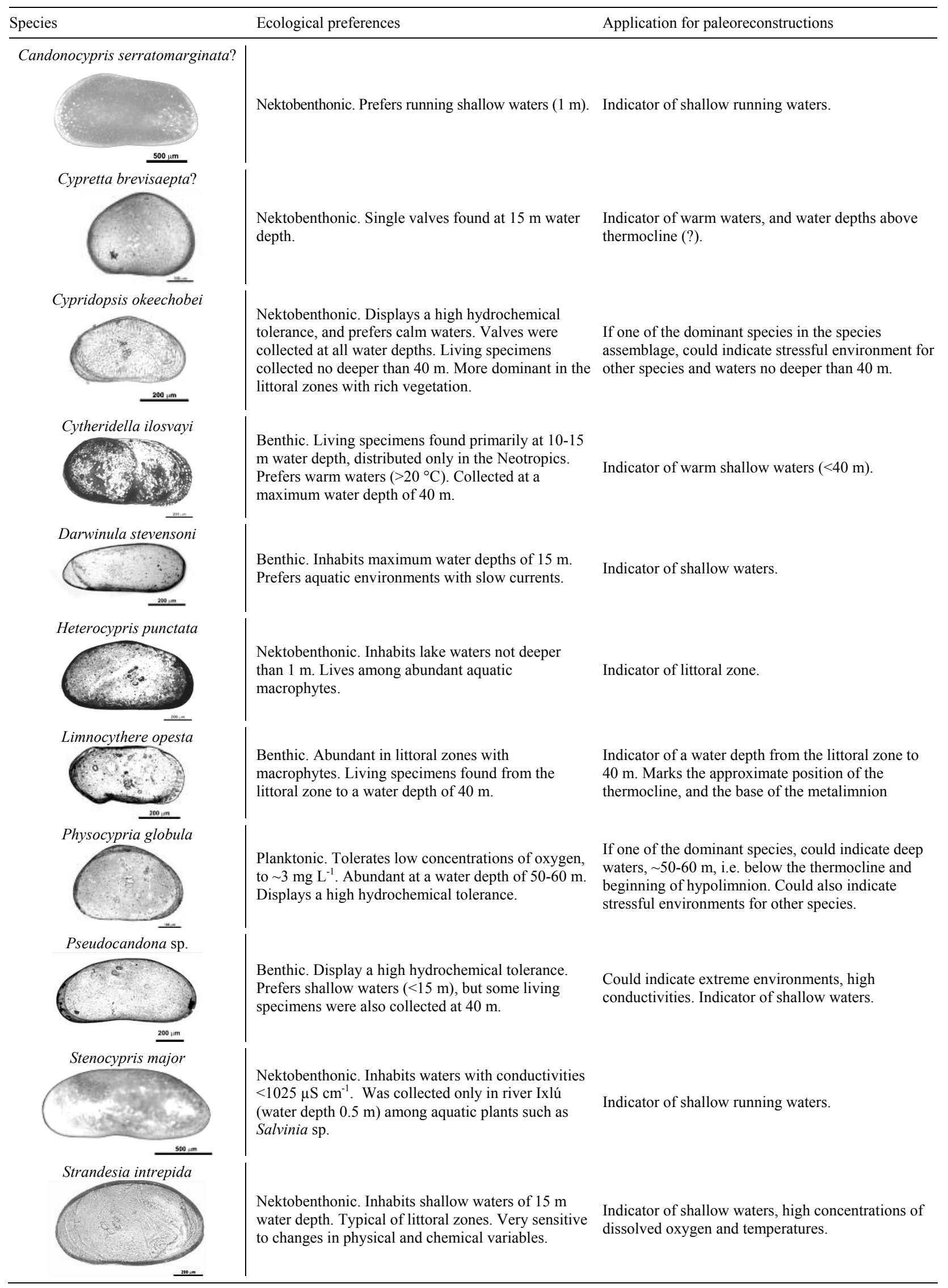


(1) littoral zone (Heterocypris punctata, Strandesia intrepida), (2) water depths from the littoral zone to the base of the thermocline (Cypretta brevisaepta?, Cytheridella ilosvayi, Darwinula stevensoni, Limnocythere opesta, Pseudocandona sp.), and (3) water depths below the thermocline (Physocypria globula). Candonocypris serratomarginata? and Stenocypris major are indicative of shallow running waters. Limnocythere opesta and $C$. ilosvayi are benthic species marking the location of the thermocline. Our results showed that the distribution of $C$. okeechobei and $P$. globula are not correlated with changes in physicochemical variables, indicating their broad hydrochemical tolerance. To make more effective use of ostracodes as proxies for environmental reconstructions in Lago Petén Itzá, studies are needed in which ostracode juvenile instars are included. This approach might reveal if species collected were actually living at the sampling location, or were transported to the sampling site by water currents. Understanding ostracode ecology is difficult because seasonal (temporal) and spatially-related environmental factors, as well as life-history characteristics, influence the sampled assemblages. More studies on ostracode communities, with respect to seasonal variation, vertical migration, spatial distribution, and hydrochemical and substrate analyses, are required to better understand ostracode ecology.

\section{ACKNOWLEDGMENTS}

We thank Evgenia Vinogradova and Wolfgang Riss (Department of Limnology, Institute for Evolution and Biodiversity, University of Münster) for their assistance during the field campaign of 2005. Michael Hupfer (Institute of Freshwater Ecology and inland Fisheries, Berlin) measured total phosphorus in water samples. Special thanks to Raúl Calderón for drafting the maps. We are also grateful for the help provided by Denise Samol, Susanne Krueger (University of Braunschweig), Margarita Palmieri, Margaret Dix, Roberto Moreno, and Eleonor de Tott (Universidad del Valle de Guatemala), Franklin Herrera and Jose Luis López (Consejo de Áreas Protegidas, CONAP, Guatemala), Autoridad para el Manejo y Desarrollo Sostenible de la cuenca del Lago Petén Itzá (AMPI, Guatemala), Instituto de Sismología, Vulcanología, Meteorología e Hidrología, (INSIVUMEH, Guatemala), Gerald Islebe (ECOSUR-Chetumal, Mexico) and Jason Curtis (University of Florida). We are grateful to Peter Frenzel (University of Jena) for his help with statistical analyses, to Claudia Wrozyna and Douglas Schnurrenberger for helpful comments and Harald Biester (University of Braunschweig) for discussion. This research was funded by the Deutsche Forschungsgemeinschaft (grant Schw 671/3) and start-up money provided by the University of Braunschweig.

\section{REFERENCES}

Anselmetti, F.S., D. Ariztegui, D.A. Hodell, M.B. Hillesheim, M. Brenner, A. Gilli, J.A. McKenzie \& A.D. Müller. 2006. Late Quaternary climate-induce lake level variations in Lake Petén Itzá, Guatemala, inferred from seismic stratigraphic analysis. Palaeogeogr., Palaeoclimateol., Palaeoecol., 230: 52-69.

Basterrechea, M. 1988. Limnología del Lago Petén Itzá, Guatemala. Rev. Biol. Trop., 36: 123-127.

Brehm, V. 1939. La Fauna Microscópica del Lago Petén, Guatemala. An. Esc. Nac. Cienc. Biol., 1: 173-204.

Brenner, M., M. Rosenmeier, D.A. Hodell, J.H. Curtis, F. Anselmetti \& D. Ariztegui. 2002. Limnología y paleolimnología de Petén, Guatemala. Revista Universidad del Valle de Guatemala, 12: 2-9.

Brezonik, P.L. \& J.L. Fox. 1974. The limnology of selected Guatemalan lakes. Hydrobiologia, 45: 467-487.

Bridgwater, N.D., J. Holmes \& S.L. O'Hara. 1999. Complex controls on the trace-element chemistry of non-marine ostracods: an example from Lake Pátzcuaro, central Mexico. Palaeogeogr., Palaeoclimateol., Palaeoecol., 148: 117131.

Cohen, A. \& G. Morin. 1990. Patterns of Reproduction in Ostracodes: A Review. J. Crustacean Biol., 10: 184-211.

Curtis, J., D. Hodell \& M. Brenner. 1996. Climate variability on the Yucatan Peninsula (Mexico) during the Past 3500 years, and implications for maya cultural evolution. Quaternary Res., 46: 37-47.

Curtis, J. H., M. Brenner, D.A. Hodell, R.A. Balser, G.A. Islebe \& H. Hooghiemstra. 1998. A multi-proxy study of Holocene environmental change in the Maya Lowlands of Peten, Guatemala. J. Paleolimnol., 19: 139-159.

De Deckker, P. 1983. Notes on the ecology and distribution of non-marine ostracods in Australia. Hydrobiologia, 106: 223-234.

Deevey, E.S., G.B. Deevey \& M. Brenner. 1980. Structure of zooplankton communities in the Peten Lake District Guatemala. In: W.C. Kerfoot (Ed.), The Evolution and Ecology of Zooplankton Communities. University Press of New England, Hannover, New Hampshire: 669-678.

Dole-Olivier, M.J., D.M.P. Galassi, P. Marmonier \& M.C.D. Chatelliers. 2000. The biology and ecology of lotic microcrustaceans. Freshwat. Biol., 44: 63-91.

Escobar, J., J.H. Curtis, M. Brenner, D.A. Hodell \& J. Holmes. 2009. Isotope measurements of single ostracod valves and gastropod shells for climate reconstruction: evaluation of withing-sample variability and determination of optimum sample size. J. Paleolimnol., DOI 10.1007/s10933-009-9377-9.

Frenzel, P. \& I. Boomer. 2005. The use of ostracods from marginal marine, brackish waters as bioindicators of modern and Quaternary environmental change. Palaeogeogr., Palaeoclimateol., Palaeoecol., 255: 68-92.

Frenzel, P., R. Matzke-Karasz \& F. Viehberg. 2006. Muschelkrebse als Zeugen der Vergangenheit. Biol. Unserer Zeit, 2: 102-107.

Frenzel, P., C. Wrozyna, M. Xie, L. Zhu \& A. Schwalb. 2009. Paleo-water depth estimation for a 600-year record from Nam Co (Tibet) using an ostracod-based transfer function. Quatern. Int. DOI: 10.1016/j.quaint.2009.06.010.

Furtos, N. 1933. The ostracoda of Ohio. Bulletin of the Ohio Biological Survey, 29: 411-524.

Furtos, N. 1936a. On the ostracoda from the cenotes of Yucatán and vicinity. Carnegie Institution of Washington, Washington: 89-115.

Furtos, N. 1936b. Fresh-water ostracoda from Florida and North Carolina. The American Midland Naturalist, 17: 491-522.

Goulden, C.E. 1966. The history of Laguna de Petenxil: The animal microfossils. Acad. Arts Sci. Mem., 17: 84-120. 
Griffiths, H.I. \& J.A. Holmes. 2000. Non-marine ostracods and Quaternary palaeoenvironments. QRA Technical Guide No. 8, London, Quaternary Research Association: 179 pp.

Haug, G., D. Günther, L. Peterson, D. Sigman, K. Hughen \& B. Aeschlimann. 2003. Climate and the Collapse of Maya Civilization. Science, 299: 1731-1735.

Heiri, O., A.F. Lotter \& G. Lemcke. 2001. Loss on ignition as a method for estimating organic and carbonate content in sediments: reproductibility and comparability of results. $J$. Paleolimnol., 25: 101-110.

Hillesheim, M., D.A. Hodell, B.W. Leyden, M. Brenner, J.H. Curtis, F.S. Anselmetti, D. Ariztegui, D.G. Buck, T.P. Guilderson, M.F. Rosenmeier \& D.W. Schnurrenberger. 2005. Climate change in lowland Central America during the late deglacial and early Holocene. J. Quaternary Sci., 20: 363-376.

Hodell, D.A., J.H. Curtis \& M. Brenner. 1995. Possible role of climate in the collapse of Classic Maya civilization. Nature, 375:391-394.

Hodell, D.A., M. Brenner, J.H. Curtis, R. Medina-González, E. Ildefonso-Chan Can, A. Albornaz-Pat \& T.P. Guilderson. 2005. Climate change on the Yucatan Peninsula during the Little Ice Age. Quaternary Res., 63: 109-121.

Hodell, D., F. Anselmetti, M. Brenner, D. Ariztegui \& the Scientific Sampling Party. 2006. The Lake Petén Itzá Scientific Drilling Project. Scientific Drilling, 3:25-29.

Hodell, D.A., F.S. Anselmetti, D. Ariztegui, M. Brenner, J.H. Curtis, A. Gilli, D.A. Grzesik, T.J. Guilderson, A.D. Müller, M.B. Bush, A. Correa-Metrio, J. Escobar \& S. Kutterrolf. 2008. An 85-ka record of climate change in lowland Central America. Quaternary Sci. Rev., 27: 1152-1165.

Holmes, J. 1996. Trace-element and stable-isotope geochemistry of non-marine ostracod shells in Quaternary paleoenvironmental reconstruction. J. Paleolimnol., 15: 223-235.

Horne, D.J., A. Cohen \& K. Martens. 2002. Taxonomy, Morphology and Biology of Quaternary and Living Ostracoda. In: J.A. Holmes \& A.R. Chivas (Eds), The Ostracoda: Applications in Quaternary Research, Geophysical Monograph 131. American Geophysical Union, Washington, DC: $5-36$.

Ibarra-Manríquez, G., J.L. Villaseñor, R. Durán \& J. Meave. 2002. Biogeographical analysis of the tree flora of the $\mathrm{Yu}-$ catan Peninsula. J. Biogeogr., 29: 17-29.

King, J.L., M.A. Simovich \& R.C. Brusca. 1996. Species richness, endemism and ecology of crustacean assemblages in northern California vernal pools. Hydrobiologia, 328: 85-116.

Krebs, C. J. 1989. Ecological Methodology. Harper and Row, Publishers. New York: $654 \mathrm{pp}$.

Külköylüoğlu, O. 2005. Ecology and phenology of freshwater ostracods in Lake Gölköy (Bolu, Turkey). Aquatic Ecology, 39: 295-304.

Leyden, B., M. Brenner, T. Whitmore, J. Curtis, D. Piperno \& B. Dahlin. 1996. A record of long-and short term climatic variation from northwest Yucatán: Cenote San José Chulchacá. The managed mosaic. Ancient maya agriculture and resource use: $30-50$

Magurran, A.R. 1988. Ecological diversity and its measurement. Princeton Univ. Press, Princeton, New Jersey.

MARN-AMPI. 2008. Línea de Base Territorial para la Cuenca. Proyecto GU-T1021. Informe final, Ministerio de Ambiente y Recursos Naturales-Autoridad para el Manejo y Desarrollo Sostenible de la Cuenca del Lago Petén Itzá: $256 \mathrm{pp}$.

Mezquita, F., A. Sanz-Brau \& M.R. Miracle. 1996. New data on freshwater ostracod assemblages (Crustacea, Ostracoda) from Cuenca (Central Spain). Bull. Soc. Nat. luxemb., 97: 239-247.

Mezquita, F., H. I. Griffiths, S. Sanz, J.M. Soria \& A. Pinon. 1999. Ecology and Distribution of Ostracods Associated with Flowing Waters in the Eastern Iberian Peninsula. $J$. Crustacean Biol., 19: 344-354.
Mischke, S., U. Herzschuh, G. Massmann \& C. Zhang. 2007. An ostracod-conductivity transfer function for Tibetan lakes. J. Paleolimnol., 38: 509-524.

Mourguiart, P. \& P. Carbonel. 1994. A quantitative method of paleolake-level reconstruction using ostracod assemblages: an example from the Bolivian Altiplano. Hydrobiologia, 288: 183-193.

Müller, A. D., G. A. Islebe, M. B. Hillesheim, D. A. Grzesik, F. S. Anselmetti, D. Ariztegui, M. Brenner, J. H. Curtis, D. A. Hodell \& K. A. Venz. 2009. Climate drying and associated forest decline in the lowlands of northern Guatemala during the late Holocene. Quaternary Res., 71: 133-141.

Palacios-Fest, M., J. B. Mabry, F. Nials, J.P. Holmlund, E. Miksa \& O.K. Davis. 2001. Early irrigation systems in southeastern Arizona: the ostracode perspective. Journal of South American Earth Sciences, 14: 541-555.

Parker, L. A.S. Cohen, K. Martens \& R. Bralek. The impact of taphonomic processes on interpreting paleoecologic changes in large lake ecosystems: ostracodes in Lakes Tanganyika and Malawi. J. Paleolimnol., 30: 127-138.

Pérez, L., G. Alfaro, M. Palmieri, M. Dix, M. Maldonado, G. Islebe, B. Scharf \& A. Schwalb. 2008. Paleoclima y paleoecología de las tierras bajas del norte de los neotrópicos: investigación limnológica y extracción de sedimentos del lago Petén Itzá (Guatemala). Revista de la Universidad del Valle de Guatemala, 18: 65-83.

Pérez, L. J. Lorenschat, M. Brenner, B. Scharf \& A. Schwalb. (2009). Modern Freshwater Ostracodes (Crustacea: Ostracoda) from Lago Petén Itzá, Guatemala. Rev. Biol. Trop. (accepted).

Perry, E., G. Velázquez-Olimán \& R.A. Socki. 2003. Hydrogeology of the Yucatán Península. In: A.G. Pompa \& S. Fedick (Eds), The Lowland Maya Area. The Haworth Press, Inc., New York: 115-138.

Renkonen, O. 1938. Statistich-ökologische untersuchungen über die terrestrische Käferwelt der Finnischen Bruchmoore. Ann. Zool. Soc. Zool. Bot. Fenn. Vanamo, 6:1-231.

Rosenfeld, J. 2002. El potencial económico del Bloque de Yucatán en México, Guatemala y Belice. Boletín de la Sociedad Geológica Mexicana, Tomo LV (1): 30-37.

Rosenmeier, M., D. Hodell, M. Brenner, J. Curtis, J. Martin, F. Anselmetti, D. Ariztegui \& T. Guilderson. 2002a. Influence of vegetation change on watershed hydrology: implications for paleoclimatic interpretation of lacustrine $\delta^{18} \mathrm{O}$ records. J. Paleolimnol., 27: 117-131.

Rosenmeier, M., D. Hodell, M. Brenner \& J. Curtis. 2002b. A 4000 year lacustrine record of environmental change in the southern maya lowlands, Petén, Guatemala. Quaternary Res., 57: 183-190.

Scharf, B., F. Bittmann \& T. Boettger. 2005. Freshwater ostracods (Crustacea) from the Lateglacial site at Miesenheim, Germany, and temperature reconstruction during the Meiendorf Interstadial. Palaeogeogr., Palaeoclimateol., Palaeoecol., 225: 203-215.

Schmitter-Soto, J.J., F.A. Comín, E. Escobar-Briones, J. Herrera-Silveira, J. Alcocer, E. Suárez-Morales, M. Elías Gutiérrez, V. Díaz-Arce, L.E. Marín \& B. Steinich. 2002. Hydrogeochemical and biological characteristics of cenotes in the Yucatan Peninsula (SE Mexico). Hydrobiologia, 467: 215-228.

Schwalb, A. 2003. Lacustrine ostracodes as stable isotope recorders of late-glacial and holocene environmental dynamics and climate. J. Paleolimnol., 29: 256-351.

Smith, A. 1993. Lacustrine ostracodes as hydrochemical indicators in lakes of the non-central United States. J. Paleolimnol., 8: 121-134.

Smith, A.J. \& D.J. Horne. 2002. Ecology of marine, marginal marine and nonmarine Ostracodes. In: J.A. Holmes \& A.R. Chivas (Eds), The Ostracoda: Applications in Qua- 
ternary Research, Geophysical Monograph 131. American Geophysical Union, Washington, DC: 37-64.

Suárez-Morales, E. 2003. Historical biogeography and distribution of the freshwater calanoid copepods (Crustacea: Copepoda) of the Yucatan Peninsula, Mexico. J. Biogeogr., 30: 1851-1859.

Viehberg, F. 2005. Quantitative paleoenvironmental studies using freshwater ostracods in northeast Germany. $\mathrm{PhD}$ thesis, Ernst Moritz Arndt Universität Greifswald, Greifswald: $135 \mathrm{pp}$.

Whatley, R.C. 1988. Population structure of ostracods: some general principles for the recognition of paleoenvironments. In: P. De Deckker, J.P. Colin \& J.P. Peypouquet (Eds), Ostracoda in the Earth Sciences. Elsevier: 245-256.

Received: September 2009

Accepted: November 2009
Whitmore, T.J., M. Brenner, J.H. Curtis, B.H. Dahlin \& B.W. Leyden. 1996. Holocene climatic and human influences on lakes of the Yucatán Península, Mexico: an interdisciplinary paleolimnological approach. Holocene, 6: 273-287.

Wrozyna, C., P. Frenzel, A. Schwalb, P. Steeb \& L.P. Zuh. 2009. Water depth related assemblage composition of recent ostracoda in Lake Nam Co, southern Tibetan Plateau. Revista Española de Micropaleontología, 41: 20.

Yılmaz, F. \& O. Külköylüoğlu. 2006. Tolerance, optimum ranges, and ecological requirements of freshwater Ostracoda (Crustacea) in Lake Aladağ (Bolu, Turkey). Ecological Research, 21: 165-173. 